\title{
Single Fetal Death in Monochorionic Twin Pregnancy: Co-Twin Prognosis and Neonatal Outcome
}

\section{Gestação Gemelar Monocoriónica com Morte de Um dos Fetos: Prognóstico do Co-Gémeo Sobrevivente e Desfecho Neonatal}

\author{
Emídio VALE-FERNANDES $\rrbracket^{1}$, Joana DIAS ${ }^{2}$, Belandina $\mathrm{GIL}^{1,3}$, Alexandra CADILHE ${ }^{1,3}$ \\ Acta Med Port 2017 Feb;30(2):148-151 - http://dx.doi.org/10.20344/amp.7223
}

\section{ABSTRACT}

The incidence of single fetal death in twin pregnancy varies from $0.5 \%-6.8 \%$, leaving the surviving fetus with increased morbi-mortality. The prognosis is worse in monochorionic pregnancies. In addressing these cases it should be noted referral to tertiary center with differentiated perinatal support, induction of fetal lung maturation and termination of pregnancy if there's loss of fetal well-being or possibility of maternal complications and suspected neurological sequelae in the surviving fetus. The risk of iatrogenic prematurity should always be weighed with the possible consequences arising from the fetus staying in a hostile uterine environment. The authors describe a case of a 32-year-old pregnant woman with monochorionic/diamniotic twin pregnancy diagnosed with death of one of the fetuses due to fetal growth restriction and velamentous insertion of the umbilical cord at 30 weeks of gestation. The couple opted for termination of pregnancy at 33 weeks after documentation of brain changes in the surviving fetus.

Keywords: Fetal Mortality; Pregnancy Outcome; Premature Birth; Twins, Monozygotic

\section{RESUMO}

A incidência de morte fetal de um feto na gestação gemelar varia de $0,5 \%-6,8 \%$, deixando o feto sobrevivente com morbi-mortalidade aumentada. O prognóstico é pior em gestações monocoriónicas. Ao abordar estes casos importa realçar a referenciação a centro terciário com apoio perinatal diferenciado, a indução da maturação pulmonar fetal e a interrupção da gravidez se houver perda de bem-estar fetal ou possibilidade de complicações maternas ou suspeita de sequelas neurológicas no feto sobrevivente, devendo os riscos da prematuridade iatrogénica serem sempre pesados com as possíveis sequelas decorrentes da permanência do feto num ambiente uterino hostil. Os autores descrevem o caso de uma mulher de 32 anos com gravidez monocoriónica/diamniótica com morte de um dos fetos, com restrição de crescimento grave e inserção velamentosa do cordão umbilical, pelas 30 semanas de gestação. O casal optou pela terminação da gravidez às 33 semanas, após documentação de alterações cerebrais no feto sobrevivente.

Palavras-chave: Gémeos Monozigóticos; Mortalidade Fetal; Nascimento Prematuro; Resultado da Gravidez

\section{INTRODUCTION}

Multifetal pregnancies are associated with an increased risk of perinatal mortality compared to unifetal pregnancies. The incidence of single fetal death in twin pregnancy varies from $0.5 \%-6.8 \%$. The importance of chorionicity is evident in the prevalence of monochorionicity in death of one of the twins, which is around $50 \%-70 \%$. This event has potential consequences for the surviving fetus (co-twin), including increased risk of fetal death, neurological morbidity, preterm delivery (PTD) and associated sequelae..$^{1-3}$

The etiology of death of a twin often can't be determined but there're several conditions that may be associated, particularly twin-to-twin transfusion syndrome (TTTS), velamentous insertion of the umbilical cord, true umbilical cord knot, birth defects and fetal growth restriction (FGR). ${ }^{1-3}$

Chorionicity determines the prognosis of co-twin survivor, being worse in monochorionic pregnancies. The placental vascular anastomoses present in this kind of twin pregnancy are responsible for early hemodynamic changes after the death of one of the twins, and therefore not preventable by termination of pregnancy, with sudden drop in blood pressure, exsanguination, severe anemia and ischemic lesions in the white matter/brain cyst formation in the co-twin survivor. ${ }^{1-3}$

The timing of death (gestational age in which it occurs) is crucial in the future implications of twin pregnancy. ${ }^{1-3}$

\section{CASE REPORT}

The authors describe a case of a 32-year-old pregnant woman, smoking 20 cigarettes/day until the beginning of pregnancy and without other relevant medical history. III gesta I para (eutocic delivery 13 years ago, with newborn female, $3450 \mathrm{~g}$, healthy) I miscarriage. The first trimester's obstetric ultrasound diagnosed monochorionic/ diamniotic twin pregnancy; fetal abnormalities or ultrasonographic installation signs of TTTS weren't detected. The ultrasonographic screening for aneuploidies was negative. The pregnant woman began maternal and fetal surveillance in obstetrics high risk consultation having made selective scans each two weeks from 16 weeks on (TTTS screening). During this evaluation the TTTS

1. Serviço de Ginecologia e Obstetrícia. Hospital de Braga. Braga. Portugal.

2. Serviço de Pediatria. Hospital de Braga. Braga. Portugal.

3. Unidade de Medicina Fetal e Diagnóstico Pré-Natal. Serviço de Ginecologia e Obstetrícia. Hospital de Braga. Braga. Portugal.

$\triangle$ Autor correspondente: Emídio Vale-Fernandes. emidio.vale.fernandes@gmail.com

Recebido: 19 de novembro de 2015 - Aceite: 31 de agosto de 2016 | Copyright @ Ordem dos Médicos 2017 


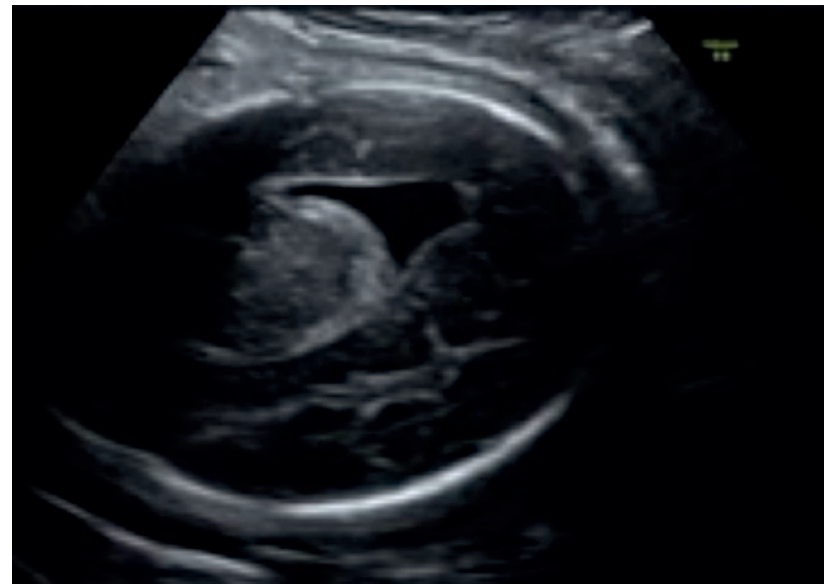

Figure 1 - Obstetric Ultrasound - 32 weeks of gestation - abnorma justaventricular image with apparent cerebral ventricular dilation

was always excluded. At 22 weeks it was documented normal fetal echocardiograms. At 25 weeks, fetus two was diagnosed with FGR; the pregnant woman initiated weekly fetal monitoring with ultrasound (including umbilical artery (UA) and middle cerebral artery (MCA) fluxometries) and cardiotocography (biophysical profile), whose results were never altered; fetus two maintained severe FGR in the biometric revaluation each two weeks. At 30 weeks, death of fetus two was diagnosed (affected with severe FGR); fetus one had growth and UA and MCA fluxometries were kept within the normal range. Surveillance began with weekly fetal ultrasound evaluation (including cerebral ecoanatomy) and biweekly cardiotocography. Maturation of the fetal lung maturity with betamethasone was performed. One abnormal justaventricular image was diagnosed with apparent cerebral ventricular dilation in the surviving fetus at 32 weeks (Fig. 1), which led to the realization of fetal brain magnetic resonance imaging (MRI) which revealed focal changes in the periventricular white matter, particularly in peri-trigonal regions bilaterally, that may correspond to hypoxic-ischemic lesions with evolution greater than one week, and left ventricle with about $10.5 \mathrm{~mm}$ of greater diameter (Fig. 2). Given the brain changes in the surviving fetus, the couple decided to terminate the pregnancy. An elective caesarean section was performed for termination of pregnancy (33 weeks), with male newborn with $1850 \mathrm{~g}$ hospitalized in Neonatology for surveillance by prematurity.

The histological examination revealed monochorionic/ diamniotic placenta weighing less than expected, with velamentous insertion of the umbilical cord, calcifications and hyalinized villi in placental area in relation to fetus two.

The evolution of the newborn in Neonatology was favorable with neurological examination without changes. The transfontanellar ultrasound (TU) on the second day of life revealed focal lesions likely to represent ischemic insult (Fig. 3A). Repeated TU on the fifteenth day of life (discharge day) showed bilateral paratrigonal hyperechogenicity outbreaks. At two months of life the newborn had good weight progression, neurological examination without changes, adequate psycho-motor development and TU with fine and imprecise brain changes (Fig. 3B).

After four years of follow up, the child shows spastic hemiparesis of the lower left- member with hypertonia and hyperreflexia, but his growth and development are age appropriate. The latest brain MRI scan was normal.

\section{DISCUSSION}

The approach and the timing of the termination of pregnancy in cases of death of one twin in early gestational ages where the fetal viability is not yet established are not consensual, being necessary to weigh the risk of iatrogenic prematurity with the risk of staying in a hostile uterine environment. Present recommendations are limited because of the absence of randomized controlled trials. Some authors advocate a conservative approach until 37 weeks of pregnancy, if documented fetal well-being, because an early obstetric intervention may be associated with iatrogenic prematurity and increased neurological morbidity of the surviving fetus, compared with the expected effects of death of one of the twins in the co-twin survivor. ${ }^{1-3}$

Determining the mode of delivery should be considered by obstetric criteria and by prematurity with the possibility of vaginal delivery. The approach should always be individualized, with support and advice tailored to parents. In addressing these cases it should be noted referral to tertiary center with differentiated perinatal support, induction of fetal lung maturation and termination of pregnancy if there is loss of fetal well-being or risk of serious maternal complications and suspected neurological sequelae in the surviving fetus. ${ }^{1-3}$

As a prognostic predictor of cerebral palsy, the abnormalities detected by cerebral MRI near full term allow to predict neurodevelopmental disorders of the child.
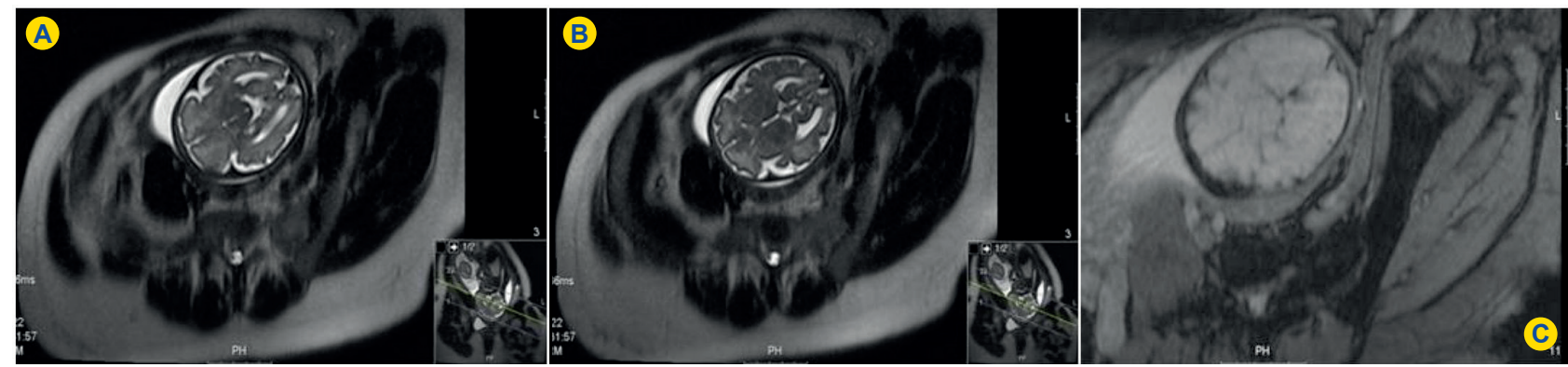

Figure 2 - Fetal cerebral MRI - 32 weeks of gestation - signal focal changes in the periventricular white matter, which may correspond to hypoxic-ischemic lesions with evolution greater than one week 

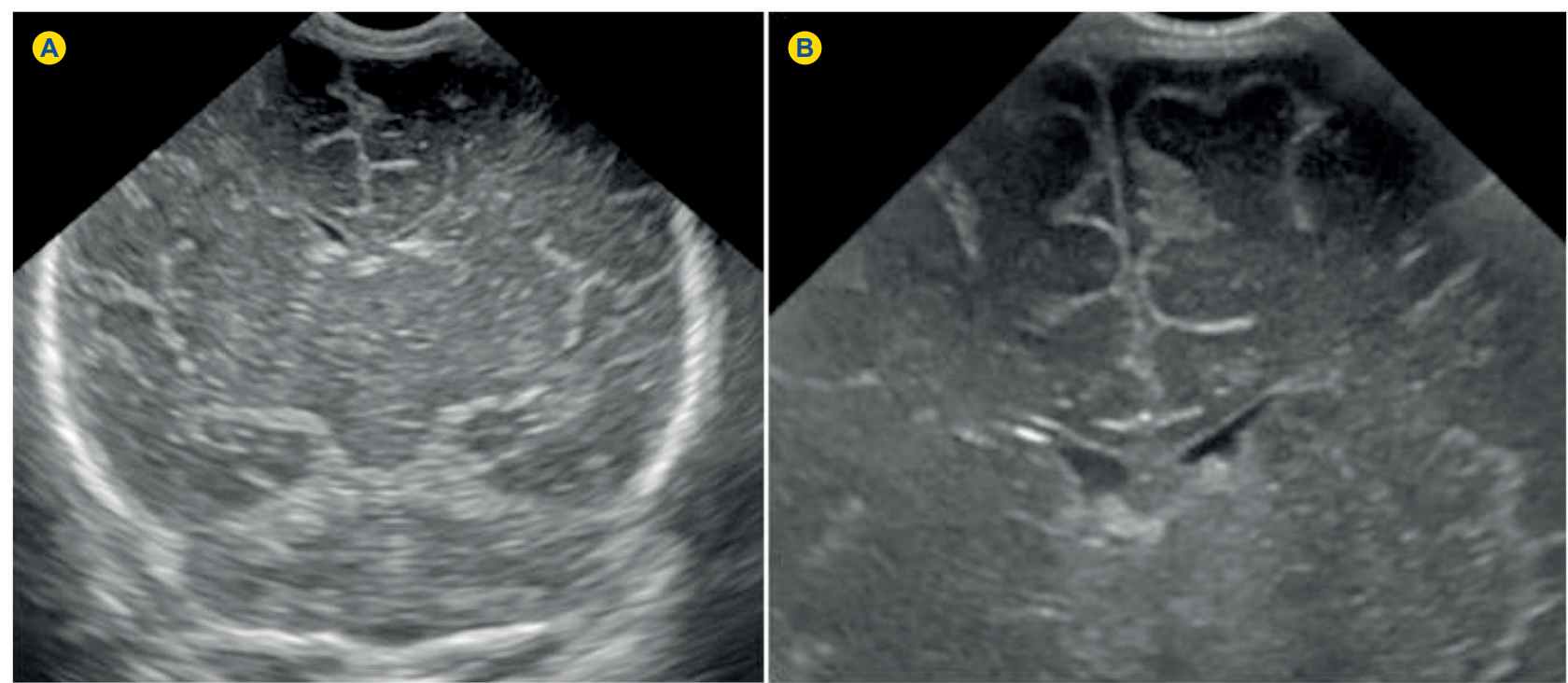

Figure 3 - Newborn transfontanelar ultrasound: (A) second day of life - focal hyperechoic periventricular lesions, predominantly on the left, which are associated with extensive hyperechogenicity in the periventricular white matter, in relation with probable ischemic etiology. (B) Two months of age (real age) - few small hyperechoic foci of imprecise nature.

However, it is important to point out that a substantial proportion of children with moderate to severe changes in white matter have normal neurodevelopment, although a longer follow up is needed. ${ }^{3-6}$

In the case presented, the death of one of the monochorionic twins was due to severe FGR, with probable origin in velamentous insertion of the umbilical cord. Imaging changes that could translate to possible neurological sequelae of the surviving fetus led the couple to choose the termination of pregnancy at 33 weeks by caesarean section, but medical advice was conducted in order to warn that the identified neurological disorders originated in the death of co-twin (already installed and to expressing the expected natural history) and the termination of pregnancy in this time could bring more complications associated with prematurity. ${ }^{1-3}$

TTTS is a potential complication of $5 \%-15 \%$ of monochorionic pregnancies that if left untreated can be associated with $90 \%$ of perinatal mortality. ${ }^{7}$ In the surveillance of a monochorionic pregnancy this complication should always be actively searched. In the present case report TTTS was never detected. The ultrasonographic signs of TTTS installation are in the first trimester of pregnancy the disagreement of the skull-rump length or nuchal translucency $(>20 \%$ ) of fetuses, the existence of a nuchal translucency upper the $95^{\text {th }}$ percentile in one of the fetuses or presence of an inverted a wave in the ductus venosus of at least one of the fetuses ${ }^{8}$; in the second trimester the presence of TTTS is defined as the appearance of oligo/ hydramnios sequence. ${ }^{7}$

The pediatric follow up carried out showed minor changes in the psycho-motor development of the child born.

\section{PROTECTION OF HUMANS AND ANIMALS}

The authors declare that the procedures described in this article followed the regulations of their Institution' Clinical Research and Ethics Committee and the Helsinki Declaration of the World Medical Association.

\section{CONFLICTS OF INTEREST}

The authors declare no conflict of interest in conducting this work. This work was one of the clinical cases selected for the commemoration of the 70 years in health of the CUF Group and will be published in the book of the event that will be distributed to employees of the José de Mello Saúde.

\section{FUNDING SOURCES}

The authors declare that this work was not subject to any financing.

\section{REFERENCES}

1. Hillman SC, Morris RK, Kilby MD. Co-twin prognosis after single fetal death - a systematic review and meta-analysis. Obstet Gynecol. $2011 ; 118: 4,925-40$

2. Ong SS, Zamora J, Khan KS, Kilby MD. Prognosis for the cotwin following single-twin death: a systematic review. BJOG. 2006;113:9928.

3. Woo HH, Sin SY, Tang LC. Single foetal death in twin pregnancies: review of the maternal and neonatal outcomes and management. Hong Kong Med J. 2000;6:293-300.

4. Mirmiran M, Barnes PD, Keller K, Constantinou JC, Fleisher BE, Hintz $\mathrm{SR}$, et al. Neonatal brain magnetic resonance imaging before discharge is better than serial cranial ultrasound in predicting cerebral palsy in very low birth weight preterm infants. Pediatrics. 2004;114:992-8.

5. Valkama AM, Pääkkö EL, Vainionpää LK, Lanning FP, Ilkko EA, Koivisto ME. Magnetic resonance imaging at term and neuromotor outcome in preterm infants. Acta Paediatr. 2000;89:348-55.

6. Woodward LJ, Anderson PJ, Austin NC, Howard K, Inder TE. Neonata $\mathrm{MRI}$ to predict neurodevelopmental outcomes in preterm infants. $\mathrm{N} \mathrm{Engl}$ J Med. 2006;355:685-94.

7. Carraca T, Cruz-Pires M, Loureiro T, Cunha M, Rodrigues T, Matias A. Complicações da gravidez gemelar monocoriónica - orientação clínica. In: Montenegro N, Rodrigues T, Ramalho C, Ayres-de-Campos D, 
editores. Protocolos de medicina materno-fetal. $3^{\text {a }}$ ed. Lisboa: Lidel Edições Técnicas, Lda.; 2014. p. 184-7.

8. Rodrigues T, Ramos F, Matias A, Cruz-Pires M, Carraca T. Vigilância da gravidez múltipla. In: Montenegro N, Rodrigues T, Ramalho C, Ayresde-Campos D, editores. Protocolos de medicina materno-fetal. $3^{\mathrm{a}}$ ed. Lisboa: Lidel - Edições Técnicas, Lda.; 2014. p. 8-9.

\section{Syndrome of Irreversible Lithium-Effectuated NeuroToxicity}

Ana Luísa SILVAR1', Carolina OURIQUE1, Filipe MARTINS1', Fernando FRIÕES

Acta IMed Port 2017 Feb;30(2):151-153 - http://dx.doi.org/10.20344/amp.7907

\section{RESUMC}

- If́tio é um fármaco com janela terapêutica estreita, exigindo monitorização frequente dos seus níveis séricos e da clínica, pois toxicidade pode surgir mesmo com niveis terapêuticos. Apresentamos o caso de um homem com intoxicação por lítio, com persistência de alteraç̃es neurológicas mesmo após normalização dos seus níveis séricos, permitindo-nos fazer o diagnóstico de síndrome de neurotoxicidade irreversivel causada pelo lítio (SILENT)

Palavras-chave: Litio/efeitos adversos; Sindromes de Neurotoxicidade/etiologia

\section{ABSTRACT}

Lithium has a narrow therapeutic window. Frequent monitoring of both serum levels and clinical signs of toxicity is warranted because toxicity may be present even when concentrations are within the therapeutic range. We report the case of a man with lithium poisoning with persistent neurologic signs and symptoms even after removal of lithium from circulation - a diagnosis of syndrome of irreversible lithium-effectuated neurotoxicity (SILENT) was made

Keywords: Lithium/adverse effects; Neurotoxicity Syndromes/etiology

\section{INTRODUCÃC}

lítio tem como principal indicação a doença bipolar. É um fármaco de excreção renal, de forma semelhante ao sódio, e é dialisável. ${ }^{12}$ Tem uma janela terapêutica estreita, exigindo ajuste progressivo das doses, de acordo com os níveis séricos, a resposta clínica e o aparecimento de efeitos laterais. Concomitantemente, exige uma monitorização regular da função renal, tiroidéia e cardiovascular, e ainda do equilíbrio hidroelectrolítico (a cada seis meses no minimo). ${ }^{2}$ Deve ser utilizado com precaução quando associado a fármacos que alterem a excreção de sódio Tanti-inflamatórios não esteróides (AINEs), diuréticos tiazídicos, inibidores da enzima de conversão da angiotensina (iECAs) ou antagonistas dos receptores da anqiotensina II (ARAs) $]^{2}$ bem como ao associá-lo a fármacos neurolépticos. A sua toxicidade relaciona-se com os niveis séricos; no entanto, pode ocorrer mesmo sob niveis terapêuticos, ${ }^{1}$ sendo potenciada pela desidratação ou pela deterioracão da função renal. As principais manifestações clínicas são as gastrointestinais (náuseas, vómitos, diarreia) e as neurológicas (lentificação, fala arrastada, ataxia, confusão, agitação, irritabilidade neuromuscular, tremor, fasciculações nioclonias; em casos graves, convulsões, estado de mal רão convulsivo, encefalopatia). O tratamento passa por hidratação endovenosa e hemodiálise.

\section{CASO CLÍNICO}

Apresentamos o caso de um homem de 66 anos de idade, com história de hipertensão arterial (sob bisoprolo e associação de irbesartan com hidroclorotiazida), diabe. tes mellitus tipo 2 (sob metformina e gliclazida), doença renal crónica estádio 3, hipotiroidismo e doença bipola sob terapêutica com lítio 400 mg duas vezes por dia há mais de 20 anos, fluvoxamina e lorazepam, sem seguimen. to ou controlo analítico há cerca de três anos. Foi levadc ao Serviço de Urgência (SU) pela esposa, por agitação $€$ descoordenação motora. A esposa descrevia quadro con cerca de três meses de evolucão, constituído por disp. neia de esforco com aqravamento progressivo, ortopneia e edema dos membros inferiores, associado a irritabilida. de, ansiedade, agitação, inquietude, insónia, anorexia $\epsilon$ diarreia intermitente. Tinha sido observado recentemente pela Psiquiatria no SU, tendo tido alta com alterações da terapêutica psicotrópica. Foi posteriormente reavaliado pela Psiquiatra assistente, que introduziu terapêutica diu. rética e referenciou o doente ao Médico Assistente para doseamento de lítio. À admissão no SU, apresentava-se desorientado no tempo, agitado, confuso e lentificado, com ataxia e tremor generalizado, bem como fasciculações dos membros superiores. Sem défices neurológicos focais. Pa. râmetros vitais estáveis, dentro dos limites da normalidade. 